\title{
Natural Radioactivity and the Evaluation of Related Radiological Risks in Concrete Used in Prizren District, Kosovo
}

\author{
M. Qafleshi ${ }^{1}$, M. K. Xhixha ${ }^{2}$, G. Nafezi ${ }^{3 *}$, D. Kryeziu ${ }^{1}$, D. Qafleshi ${ }^{1}$ \\ ${ }^{1}$ University for Business and Technology, Kalabria, 10000 Prishtina, Kosovo \\ ${ }^{2}$ University Aleksandër Moisiu Durrës, Faculty of Professional Studies, Str. Currila 14, Durrës, Albania \\ ${ }^{3}$ University of Prishtina "Hasan Prishtina", Faculty of Mathematical and Natural Sciences, \\ Str. "Nëna Terezë", no.n.,10000 Prishtina, Kosovo
}

\section{ARTICLE INFO}

Article history:

Received 18 May 2021

Received in revised form 2 August 2021

Accepted 2 August 2021

Keywords:

Natural radioactivity

Activity concentration

Radiological risks

Concrete

\begin{abstract}
A B S T R A C T
This study aims to investigate the natural radioactivity levels in concrete made of Portland cement and used in Prizren district, Republic of Kosovo. The activity concentrations of ${ }^{40} \mathrm{~K},{ }^{226} \mathrm{Ra}$ and ${ }^{232} \mathrm{Th}$ were determined by gamma-ray spectroscopy technique with High Purity Germanium (HPGe) detector. The activity concentrations of ${ }^{40} \mathrm{~K},{ }^{226} \mathrm{Ra}$, and ${ }^{232} \mathrm{Th}$ were found to be $15.4-28.4 \mathrm{~Bq} \mathrm{~kg}^{-1}$, 4.3-5.9 Bq kg${ }^{-1}$ and $2.0-4.1 \mathrm{~Bq} \mathrm{~kg}^{-1}$, respectively. These results were used to calculate the activity concentration index as recommended by the Basic Safety Standard of Council Directive 2013/59/EURATOM for the safe use of building material. Kosovo must comply with this recommendation in the framework of legislative harmonization with the European Union. The activity concentration index was found to be lower than the reference level of unity $(I=0.05)$, corresponding to an annual effective dose rate of $\mathrm{AED}=0.05 \mathrm{mSv} \mathrm{y}^{-1}$. The concentration of radionuclides and radiological hazard parameters for concrete investigated in this study were compared with respective results found in literature from different countries. These results show very low activity concentrations, indicating that concrete used in Prizren, Kosovo, does not pose any significant risk due to its use as building material.
\end{abstract}

(C) 2021 Atom Indonesia. All rights reserved

\section{INTRODUCTION}

Ionizing radiation from minerals and raw materials containing radionuclides of natural origin is constantly present in the environment. These radionuclides were formed during the Earth's formation and are still found in the crust. As a consequence, they are the primary source of radiation from soils and rocks, which are consequently found in building materials. Regarding the radiation protection, the most relevant are radionuclides in the ${ }^{238} \mathrm{U}$ and ${ }^{232} \mathrm{Th}$ decay series and the radioisotope of ${ }^{40} \mathrm{~K}$ [1]. Therefore, humans are permanently exposed against indoor radiation due to building materials containing these radionuclides. Another important aspect is that the presence of ${ }^{226} \mathrm{Ra}\left({ }^{238} \mathrm{U}\right.$ chain $)$

*Corresponding author.

E-mail address: gazmend.nafezi@uni-pr.edu

DOI: https://doi.org/10.17146/aij.2021.1149 and ${ }^{232} \mathrm{Th}$ can contribute to the concentration of indoor radon gas and in particular the radon isotopes of ${ }^{222} \mathrm{Rn}$ and ${ }^{220} \mathrm{Rn}$ and its progeny. Elevated concentration can lead to internal exposure of the respiratory ways [2]. As the concentrations of these radionuclides are not uniformly distributed in the environment, from where all raw and building materials are extracted, their concentrations have a broad range from one place to another. Since most people spend about $80 \%$ of their time indoors, determining the activity concentrations of radionuclides in building materials is critical for determining the population exposure [3].

In Kosovo around $3 \mathrm{Mm}^{3}$ of concrete (around $7 \mathrm{Mt}$ ) are used annually in the construction sector. Out of this, around $2 \mathrm{Mm}^{3}$ of concrete are used as ready mixed concrete, the rest is used for producing concrete blocks, beams, masonry mortars, etc. Considering $1.8 \mathrm{M}$ 
inhabitants from the recent census in Kosovo, it comes that around 4 tons of concrete per capita are used annually. According to the International Standard Organization (ISO), the world annual production per capita is $4.7 \mathrm{t}$ of concrete [4]. In the construction sector, approximately $40 \%$ of concrete is used for high-rise buildings (apartments/blocks/public service facilities, schools, hospitals, etc.), $30 \%$ for road infrastructure (roads, bridges, viaducts, etc.) and the rest about $30 \%$ for traditional construction like private residential houses. Concrete, in principle is defined as a mixture of aggregates, cement and water. Knowing that the percentage of aggregates in concrete is around $80 \%$ by mass, it comes that for production of $7 \mathrm{Mt}$ of concrete around 5.6 Mt of fine and coarse aggregates are used annually in concrete industry, mainly extracted from rock quarries.

Considering that in Kosovo concrete is the most important and commonly used building material, the focus of this investigation was to study the natural radionuclides present in different concrete samples. The aim was to determine the activity concentration of ${ }^{226} \mathrm{Ra},{ }^{232} \mathrm{Th}$, and ${ }^{40} \mathrm{~K}$ in order to calculate the radiological hazard to the population due to the use of concrete as building material. This first study was interested in the area of Prizren district, which will give the baseline information regarding the radiological hazard of building materials used in Kosovo and check their compliance with the European standards.

\section{MATERIALS AND METHOD OF MEASUREMENT}

\section{Materials}

Geologically, Kosovo is rich with carbonate rock deposits in the form of limestone, marble and dolomite in respective quantities of $7690 \mathrm{Mm}^{3}$, $2186 \mathrm{Mm}^{3}$, and $1.4 \mathrm{Mm}^{3}$. There are 383 mining fields from where these rocks are excavated for use in industry. Almost all concrete manufacturing plants in Kosovo use crushed aggregates with carbonate rock origin [5]. The area of this study was Prizren district in southern part of Kosovo, as shown in Fig. 1, which occupies $20 \%$ of Kosovo's area. To determine the levels of natural radioactivity in concrete, first certain quantities of crushed aggregates from three different quarries, in different locations within Prizren district were collected during a period of one month.

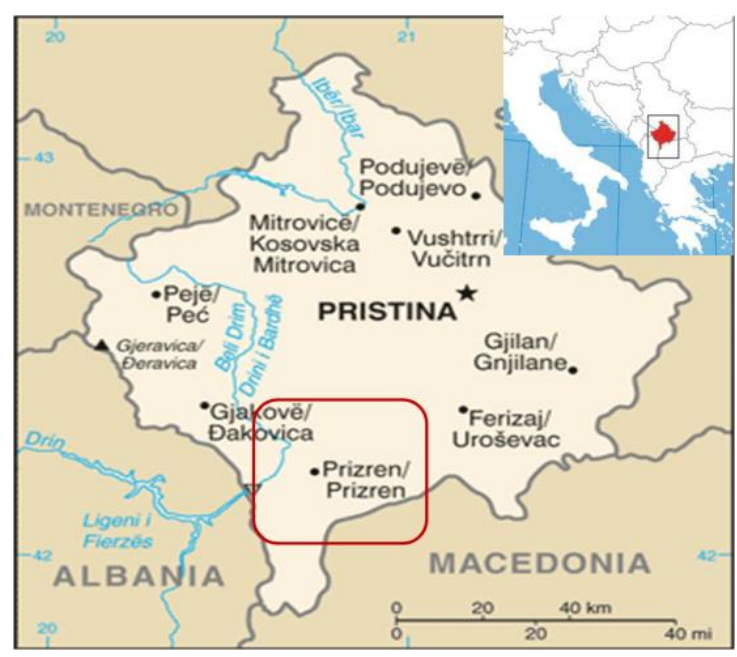

Fig. 1. Map of Kosovo and its districts.

As the mineralogical analyses of aggregates showed to have the same composition (limestone), here are described in detail the aggregates from the quarry and concrete plant "Vëllezërit e Bashkuar", Prizren. The petrographic examination of the crushed aggregate has been conducted following EN 932-3 [6]. The examination regarding the macroscopic description shows that this aggregate is light-grey to grey, unbedded, unweathered, non-porous and compact rock, with good cohesion. Open cracks, which are very rare, are usually in the form of stylolitic structures filled with soft reddish material (clay minerals and limonites). Some of them are cemented with coarse-grained calcite. Massive homogenous structure of the rock is revealed. The microscopic analysis under polarizing light shows that the rock sample has a sparitic texture. The average grain size of the sparry calcite is $150 \mu \mathrm{m}$ in diameter. The rock is very pure calcite, only in some areas traces of clay are observed. The stylolitic seams are filled with clay minerals, with rare traces of ferrous hydroxides. On the basis of the mineralogical composition, degree of crystallinity, structural and textural properties, the analyzed rock belongs in the group of medium grained calcite limestone. The estimated quantitative mineralogical composition (vol. \%) shows that this aggregate is $99.5 \%$ calcite and contains only $0.5 \%$ of clay, and rare traces of ferrous hydroxides. The specific weight of the fine and coarse aggregates is $2709 \mathrm{~kg} \mathrm{~m}^{-3}$, bulk density (compacted) $1523 \mathrm{~kg} \mathrm{~m}^{-3}$, and bulk density (loose) $1383 \mathrm{~kg} \mathrm{~m}^{-3}$.

From the collected aggregates from three quarries, three concrete mixtures with aggregates from each quarry were designed and produced. 
Concrete mixtures were made with ordinary Portland cement (OPC) type CEM I $52.5 \mathrm{~N}$ from a local cement production factory in Kosovo. This type of cement has a density of $3.1 \mathrm{~g} \mathrm{~cm}^{-3}$ and fineness of particles (Blaine) of $3027 \mathrm{~cm}^{2} \mathrm{~g}^{-1}$. The XRF analyses of CEM I 52.5 N SK EN 196-2 showed the following chemical composition in percentage by mass: $20.37 \%$ of $\mathrm{SiO}_{2}, 64.71$ of $\mathrm{CaO}, 5.60 \%$ of $\mathrm{Al}_{2} \mathrm{O}_{3}, 3.9013 .5 \%$ of $\mathrm{Fe}_{2} \mathrm{O}_{3}$, $2.7 \%$ of $\mathrm{MgO}, 2.33 \%$ of $\mathrm{SO}_{3}, 1.12 \%$ of $\mathrm{LOI}$, and $1.12 \%$ insoluble residue. The water used in concrete mixtures was drinking water from the water system. The mixtures of concrete materials were done following all procedures given in European standard for concrete [7], cement [8], aggregates in conrete (EN 12620 2013), and standard for mixing water in concrete (SK EN 1008 2007).

The content of ingredients in the designed and produced concrete mixture in $\%$ by mass were: $13 \%$ cement, $8 \%$ water and $79 \%$ of fine and coarse aggregates. The water-cement ratio was 0.6. The designed concrete strength class was C25/30, which belongs to normal concrete. From all 9 concrete mix designs, 27 concrete cubic specimens with dimensions of $15 \mathrm{~cm}$ were produced. These hardened cubic concrete specimens were properly cured in laboratory conditions for 28 days in a constant temperature of $(20 \pm 2){ }^{\circ} \mathrm{C}$.

\section{Gamma ray spectrometry measurement}

Hardened concrete samples were crushed into approximately $2 \mathrm{~cm}$ grain size and then ground to $2 \mathrm{~mm}$ gian size powder in order to homogenize the material. The material was then dried until constant weight was obtained and transferred in cylindrical containers of volume of $180 \mathrm{~cm}^{3}$. The containers were tightly sealed and appropriately stored prior to the measurement in order to re-establish the equilibrium in the ${ }^{226} \mathrm{Ra}$ decay chain.

Finally, samples were measured using a high-resolution gamma-ray spectrometry system described in details in Xhixha et al. 2016 [9]. The system comprises two $60 \%$ relative efficiency coaxial p-type HPGe gamma-ray detectors and was calibrated for the full-energy photo-peak efficiency with an uncertainty of less than $5 \%$. The main gamma emissions of radon progenies of ${ }^{214} \mathrm{~Pb}$ and ${ }^{214} \mathrm{Bi}$ were used to determine the activity concentration of ${ }^{226} \mathrm{Ra}$ assumed in equilibrium. The activity concentration of ${ }^{232} \mathrm{Th}$ was determined through gamma emissions of ${ }^{228} \mathrm{Ac}$, ${ }^{212} \mathrm{~Pb}$ and ${ }^{208} \mathrm{Tl}$. On the other hand, the activity concentration of $40 \mathrm{~K}$ is determined through its only direct gamma emission [10].

\section{RESULTS AND DISCUSSION}

\section{Activity concentrations}

The mean activity concentrations of ${ }^{40} \mathrm{~K}$, ${ }^{226} \mathrm{Ra}$, and ${ }^{232} \mathrm{Th}$ and the corresponding standard deviation ( $\mathrm{k}=1$ confidence level) for concrete samples used in Kosovo are reported in Table 1. The range of the variation of the activity concentrations is also reported. These results are compared with values reported by different countries in literature. The activity concentrations of ${ }^{40} \mathrm{~K},{ }^{226} \mathrm{Ra}$ and ${ }^{232} \mathrm{Th}$ ranged from 15.4 to $28.4 \mathrm{~Bq} \mathrm{~kg}{ }^{-1}$ with an average value of $24.8 \pm 2.5 \mathrm{~Bq}$ $\mathrm{kg}^{-1}, 4.3-5.9 \mathrm{~Bq} \mathrm{~kg}^{-1}$ with a mean value of $4.7 \pm 0.6$ $\mathrm{Bq} \mathrm{kg}$ and 2.0-4.5 $\mathrm{Bq} \mathrm{kg}{ }^{-1}$ with an average value of $4.3 \pm 0.6 \mathrm{~Bq} \mathrm{~kg}^{-1}$, respectively. The concentration of ${ }^{40} \mathrm{~K}$ in concrete is significantly lower in comparison to the activity concentration of ${ }^{40} \mathrm{~K}, \quad 181 \pm 10 \quad\left(\mathrm{~Bq} \mathrm{~kg}^{-1}\right) \quad$ of cement as given by Spahiu et al [11] that was used in all concrete designs and concrete production [11]. This is also the lowest concentration compared to other referred countries Table $1 .{ }^{40} \mathrm{~K}$ concentration is also lower compared to average value of $392 \mathrm{~Bq} \mathrm{~kg}-1$ in EU concrete, and to the world terrestrial average of $33 \mathrm{~Bq} \mathrm{~kg} \quad[1,12,13]$. The activity concentration of ${ }^{226} \mathrm{Ra},{ }^{232} \mathrm{Th}$ measured to be comparatively low with concentration in cement of Kosovo $26 \pm 2 \mathrm{~Bq} \mathrm{~kg}^{-1}, 28 \pm 3 \mathrm{~kg}^{-1}$, respectively, and very low compared with values of countries referred in Table 1 and average values in EU concrete $60 \mathrm{~Bq} \mathrm{~kg}{ }^{-1}, 35 \mathrm{~Bq} \mathrm{~kg}^{-1}$, respectively [13]. The low activity concentration of natural radionuclides in concrete samples can be explained by the low activity in aggregate such as limestone as reported in Spahiu et al. [11] where the concentrations of ${ }^{226} \mathrm{Ra},{ }^{232} \mathrm{Th}$ and ${ }^{40} \mathrm{~K}$ are found to be below detection level. The concentration values for ${ }^{226} \mathrm{Ra}$ and ${ }^{232} \mathrm{Th}$ measured in concrete were also low compared to mean levels of radium, thorium in the earth's crust, $40 \mathrm{~Bq} \mathrm{~kg}{ }^{-1}, 40 \mathrm{~Bq} \mathrm{~kg}{ }^{-1}$ and $400 \mathrm{~Bq} \mathrm{~kg}$, respectively [1]. 
Table 1. Mean and range of activity concentrations (with SD, k=1) for ${ }^{40} \mathrm{~K},{ }^{226} \mathrm{Ra}$ and ${ }^{232} \mathrm{Th}$ in concrete (C) and cement (Cem) used in Kosovo and comparison with published results from other countries and EU.

\begin{tabular}{|c|c|c|c|c|c|c|c|}
\hline \multirow{3}{*}{ Country } & \multirow{3}{*}{ Material } & \multicolumn{6}{|c|}{ Activity concetration $\left(\mathrm{Bq} \mathrm{kg}^{-1}\right)$} \\
\hline & & \multicolumn{2}{|c|}{${ }^{40} K$} & \multicolumn{2}{|c|}{${ }^{226} \mathbf{R a}$} & \multicolumn{2}{|c|}{${ }^{232} \mathrm{Th}$} \\
\hline & & mean & range & Mean & range & mean & range \\
\hline $\begin{array}{l}\text { Kosovo Present } \\
\text { study }\end{array}$ & $\mathrm{C}$ & $24.8 \pm 2.5$ & $15.4-28.4$ & $4.7 \pm 0.6$ & $4.3-5.9$ & $4.3 \pm 0.6$ & $2.0-4.5$ \\
\hline Kosovo [11] & Cem & $181 \pm 10$ & $171-181$ & $26 \pm 2$ & $24-28$ & $28 \pm 3$ & $25-31$ \\
\hline \multirow{2}{*}{ Brazil [14] } & $\mathrm{C}$ & $360 \pm 188$ & - & $7.1 \pm 5.0$ & - & $9.9 \pm 1.6$ & - \\
\hline & Cem & 564 & - & 61.7 & - & 58.5 & - \\
\hline \multirow{2}{*}{$\begin{array}{l}\text { China } \\
{[15,16]}\end{array}$} & $\mathrm{C}$ & 605.35 & $527-683$ & 15.85 & $13.7-18.0$ & 50.7 & $30.5-50.7$ \\
\hline & Cem & 703.6 & & 22.1 & & 30.4 & \\
\hline \multirow{2}{*}{ Croatia [17] } & $\mathrm{C}$ & $147 \pm 19$ & - & $11.6 \pm 1.7$ & & $14 \pm 2.7$ & - \\
\hline & Cem & $255.4 \pm 31.8$ & - & $129.6 \pm 13.7$ & - & $23.3 \pm 4.8$ & - \\
\hline \multirow{2}{*}{ Germany [18] } & $\mathrm{C}$ & 629 & 400- 1100 & 54 & $30-100$ & 57 & 23100 \\
\hline & Cem & 170 & $40-320$ & 86 & $30-200$ & 73 & $20-200$ \\
\hline \multirow{2}{*}{ Greece [18] } & $\mathrm{C}$ & 101 & $7-383$ & 40 & $22-85$ & 6 & $3-17$ \\
\hline & Cem & 257 & $32-553$ & 85 & $20-218$ & 19 & $10-41$ \\
\hline \multirow{2}{*}{ Israel [2] } & $\mathrm{C}$ & 63.6 & $30-192.3$ & 33.5 & $18.2-54.3$ & 9.2 & $33.3-20.1$ \\
\hline & Cem & 140 & - & 41 & $23-59$ & 39 & - \\
\hline \multirow{2}{*}{ Italy $[8,19]$} & $\mathrm{C}$ & $230 \pm 20$ & $230-457$ & $18 \pm 2$ & $13-23$ & $12.3 \pm 1.5$ & $12-24$ \\
\hline & Cem & 357 & $80-846$ & 41 & $7-98$ & 63 & $9-240$ \\
\hline \multirow{2}{*}{ Netherlands [12] } & $\mathrm{C}$ & 150 & $72-150$ & 22 & $15-29$ & 22 & $14-23$ \\
\hline & Cem & 230 & - & 27 & $10-49$ & 19 & $14-28$ \\
\hline \multirow{2}{*}{ Slovakia [20] } & $\mathrm{C}$ & $250 \pm 32.6$ & $227-273$ & $6.11-12.6$ & $9.38 \pm 4.6$ & $12.4-28.5$ & $20.5 \pm 11$ \\
\hline & Cem & $156.5 \pm 101$ & $36.9-331$ & $11.8 \pm 9.0$ & $3.69-36.8$ & $18.4 \pm 3.7$ & $11.8-24.9$ \\
\hline \multirow{2}{*}{ Turkey [21] } & $\mathrm{C}$ & 151 & $45-465$ & 16 & $7-27$ & 9 & $1-22$ \\
\hline & Cem & 317 & $169-476$ & 40 & $18-82$ & 26 & $8-49$ \\
\hline \multirow{2}{*}{ EU [18] } & $\mathrm{C}$ & 392 & $7-1450$ & 60 & $1-1300$ & 35 & $1-152$ \\
\hline & Cem & 216 & $4-846$ & 45 & $4-422$ & 31 & $3-266$ \\
\hline
\end{tabular}

\section{Assessment of radiological hazard}

\section{Activity concentration Index (I)}

For the potential restrictions in regard to the radiological hazard of gamma radiation due to use of a building material, the European Commission (EC) has introduced the index of activity concentration (I), by which limits or restrictions about the ways and quantity of use of that material are regulated. The activity concentration index $(I)$, in the EU Council Directive 2013/59/Euroatom [22], as well as in many national standards that regulate the radiation exposure from building materials, is calculated based on the activity concentrations of ${ }^{226} \mathrm{Ra}$ in the decay series of uranium ${ }^{238} \mathrm{U},{ }^{232} \mathrm{Th}$ in the decay series of ${ }^{232} \mathrm{Th}$, and ${ }^{40} \mathrm{~K}$ [2]. According to Council Directive 2013/59/Euroatom, the index of activity concentration $(I)$ is calculated by the Eq. (1) [22]:

$$
I=\frac{A_{40 K}}{3000}+\frac{A_{226 R a}}{300}+\frac{A_{232 T h}}{200}
$$

Where $A_{40 K}, A_{226 R a}, A_{232 T h}$ are the potassium, radium and thorium activity concentrations $\left.(\mathrm{Bq} \mathrm{kg})^{-1}\right)$ in building material. ${ }^{226} \mathrm{Ra}$ is used as reference for the parent ${ }^{238} \mathrm{U}$. As stipulated in EC RP 112 "two ranges of activity concentration index $(I)$ values have been introduced, to limit the dose to $0.3 \mathrm{mSv} \mathrm{yr}{ }^{-1}$, the $I \leq 0.5$ for use of material in bulk quantity, and $I \leq 2$ for restricted use of the material as superficial. The second dose criterion that restricts the exposure up to $1 \mathrm{mSv} \mathrm{yr}^{-1}, I \leq 2$ for the material used in bulk quantity and $I \leq 6$ for superficial and other materials with restricted use" [1]. The calculation of $I$, using the Eq. (1), as presented in Table 2, in the case of concrete made with lime stone crushed aggregate, is $0.05 \pm 0.02$, which is below the limit of 0.5 . This low value of $I$ does not impose any restriction for using of concrete in construction in 
bulk amount or as superficial material, i.e., there is no safety health risk nor further radiological analysis requirement for using it as it does not produce any high effective dose rate to the occupants living in buildings made with this concrete. As for comparison, the average activity index value in $\mathrm{EU}$ is 0.179 [2].

Table 2. Estimated activity concentration index (I), Indoor dose $\mathrm{D}$, Annual effective dose rate AED for concrete in Kosovo and other countries based on the respective activity concentration.

\begin{tabular}{|c|c|c|c|}
\hline Country & $\begin{array}{c}I \\
\text { (average) }\end{array}$ & $\underset{\left(n G y h^{-1}\right)}{D}$ & $\underset{\left(\mathbf{m S v} \mathbf{y}^{-1}\right)}{\text { AED }}$ \\
\hline Kosovo & 0.05 & 11.04 & 0.05 \\
\hline Brazil & 0.19 & 46.22 & 0.23 \\
\hline China & 0.51 & 118.09 & 0.58 \\
\hline Croatia & 0.16 & 37.83 & 0.19 \\
\hline Germany & 0.67 & 162.70 & 0.80 \\
\hline Greece & 0.20 & 51.48 & 0.25 \\
\hline Israel & 0.18 & 46.03 & 0.23 \\
\hline Italy & 0.20 & 48.49 & 0.24 \\
\hline Netherlands & 0.23 & 56.44 & 0.28 \\
\hline Slovakia & 0.22 & 39.29 & 0.25 \\
\hline Turkey & 0.15 & 36.70 & 0.18 \\
\hline EU & 0.51 & 125.06 & 0.61 \\
\hline
\end{tabular}

\section{Estimation of the absorbed gamma dose rate}

The presence of radionuclides of ${ }^{226} \mathrm{Ra},{ }^{232} \mathrm{Th}$ and ${ }^{40} \mathrm{~K}$ in concrete, i.e., in buildings made with concrete, can cause an additional gamma ray radiation, which can potentially enhance the levels of external absorbed dose rate in the indoor air. Therefore, the humans dwelling indoor are exposed to this radiation and their health may be endangered due to long staying indoors. The absorbed dose rate $\mathrm{D}\left(\mathrm{nGy} \mathrm{h} \mathrm{h}^{-1}\right)$ from activity concentrations of ${ }^{40} \mathrm{~K}$, ${ }^{226} \mathrm{Ra}$ and ${ }^{232} \mathrm{Th}$ in indoor air due to gamma-ray emission is calculated by Eq. (2) $[1,23]$ :

$$
\begin{gathered}
\mathrm{D}=0.92 A_{226 R a}+1.1 A_{232 T h} \\
+0.08 A_{40 \mathrm{~K}}
\end{gathered}
$$

Where $\mathrm{A}_{226 \mathrm{Ra}}, \mathrm{A}_{232 \mathrm{Th}}, \mathrm{A}_{40 \mathrm{~K}}$ are mean values from measured activity concentrations in $\mathrm{Bq} \mathrm{kg}^{-1}$ of ${ }^{226} \mathrm{Ra}$, ${ }^{232} \mathrm{Th}$ and ${ }^{40} \mathrm{~K}$. The conversion factors $0.92,1.1$ and 0.08 were used to convert the activity concentrations of ${ }^{226} \mathrm{Ra},{ }^{232} \mathrm{Th}$ and ${ }^{40} \mathrm{~K}$, respectively, into absorbed dose rate $D\left(\mathrm{nGy} \mathrm{h}^{-1}\right)$ at a $1 \mathrm{~m}$ height for a concrete room model proposed as in RP 112 1999. According to this model, the model room has dimensions of 4 $\mathrm{m} \times 5 \mathrm{~m} \times 2.8 \mathrm{~m}$. All structures of the room (floor, ceiling, walls) are $0.2 \mathrm{~m}$ thick and made of concrete with a density of $2350 \mathrm{~kg} \mathrm{~m}^{-3}$ [1]. The average value of the calculated indoor gamma dose rate for samples of concrete from this study as well as from some countries for comparison reason are shown in Table 2. The average of $D$ for all concrete samples was $11.04 \mathrm{nGy} \mathrm{h}^{-1}$, which is lower than $84 \mathrm{nGy} \mathrm{h}^{-1}$ of the world's mean value [13]. This $11.04 \mathrm{nGy} \mathrm{h}^{-1}$ value is also smaller than the mean calculated $(D)$ value for the referred world countries and EU average as shown in Table 2.

The annual effective dose rate $A E D\left(\mathrm{mSv} \mathrm{y}^{-1}\right)$ to an occupant from the gamma radiation, based on the room model proposed in EC RP 112 [1], was calculated from indoor absorbed dose rate $\mathrm{D}$ by "applying a conversion coefficient for the absorbed doses in the air to the effective dose received by an adult of $0.7 \mathrm{~Sv} \mathrm{~Gy}{ }^{-1}$, and the indoor occupancy factor of 0.8 " [1]. The AED is calculated based on the Eq. (3) [24]:

$$
\begin{aligned}
A E D\left(m S v y^{-1}\right)= & \mathrm{D}\left(n G y h^{-1}\right) \times 8760 \mathrm{~h} \\
& \times 0.8 \times 0.7 \mathrm{~Sv} \mathrm{~Gy}^{-1} \\
& \times 10^{-6}
\end{aligned}
$$

The calculated values of $A E D$ for concrete of Kosovo, EU and for some world countries are presented in Table 2. In the case of concrete used in Kosovo, the result is $0.05 \mathrm{mSv} \mathrm{y}^{-1}$. As compared to the global average annual effective dose rate of $0.41 \mathrm{mSv} \mathrm{y}^{-1}$, this result is extremely low [23]. This value of $A E D$ of $0.05 \mathrm{mSv} \mathrm{y}^{-1}$ confirms that the concrete meets the criteria regarding the activity index $I$, i.e., $A E D$ is less than the limit criteria of 0.3 and $1 \mathrm{mSv} \mathrm{y}^{-1}$, and can be used without any restrictions or other requirement for hazard assessment.

\section{CONCLUSIONS}

The activity concentrations of natural radionuclides in Portland cement based concrete were investigated for the first time in Prizren District, Kosovo. The activity concentration of ${ }^{226} \mathrm{Ra}$, ${ }^{232} \mathrm{Th}$ and ${ }^{40} \mathrm{~K}$ were measured by gamma ray spectrometry using a system with two HPGe detectors. The average levels of radioactive concentrations of ${ }^{40} \mathrm{~K}\left(24.8 \pm 2.5 \mathrm{~Bq} \mathrm{~kg}{ }^{-1}\right),{ }^{226} \mathrm{Ra}$ $\left(4.7 \pm 0.6 \mathrm{~Bq} \mathrm{~kg}^{-1}\right)$ and ${ }^{232} \mathrm{Th}\left(4.3 \pm 0.6 \mathrm{~Bq} \mathrm{~kg}^{-1}\right)$ are found to be relatively lower compared to the values reported in literature. This is reasonable due to the very low concentration of natural radionuclides in limestone aggregates. These results comply with the EU Directive 2013/59/EURATOM 2013 that is already implemented in Kosovo as national basic safety standard. The activity concentration index $I$ 
was found to be well below the reference level and the annual effective dose rate AED was calculated to be $0.05 \mathrm{mSv} \mathrm{y}^{-1}$. Therefore, the use of concrete (based on limestone aggregates) in building construction does not pose any significant radiological risk to the population. Further studies are needed in the country for concrete mixtures using other aggregates.

\section{ACKNOWLEDGMENT}

The authors express their greatest appreciation to Prof. L. Aliko for her valuable consults and reviewing of this paper.

\section{REFERENCES}

1. Anonymous, Radiological Protection Principles concerning the Natural Radioactivity of Building Materials, Directorate General Environment, Nuclear Safety and Civil Protection, European Commision, Luxembourg (1999) 1.

2. K. Kovler, J. Environ. Radioact. 168 (2017) 46.

3. R. C. G. M. Smetsers and J. M. Tomas, J. Environ. Radioact. 196 (2019) 40.

4. Anonymous, International Organization for Standardization ISO, ISO/TC 071 Strategic business plan, Geneva (2016) 1 .

5. Anonymous, Independent Commission for Mines and Minerals (ICMM), Republic of Kosovo, Prishtina (2020) 1.

6. Anonymous, EN 932-3:1999/A1:2004, European Committee for Standardization, Belgium, Brussels (2020) 1.

7. Anonymous, EN 206-1, European Committee for Standardization, Belgium, Brussels (2016) 1.

8. Anonymous, SK EN 197-1, Kosovo Standardization Agency, Prishtina (2019) 1.

9. G. Xhixha, G. Bezon, C. Broggini et al., J. Radional. Nucl. Chem. 295 (2013) 445.

10. G. Xhixha, M. Alberi, M. Baldoncini et.al., J. Radional. Nucl. Chem. 307 (2016) 1507.
11. E. Spahiu, G. Xhixha, M. K. Xhixha et al., Int. J. Ecosyst. Ecol. Sci. 7 (2017) 895.

12. C. Nuccetelli, S. Risica, S. Onisei et al., Natural radioactivity in building materials in the European Union: a database of activity concentrations, radon emanations and radon exhalation rates, in: Rapporti ISTISAN 17/36 (English), Istituto Superiore di Sanità, Roma (2017) 70 .

13. Anonymous, Sources and effects of ionizing radiation, United Nations Scientific Committee on the Effects of Atomic Radiation (UNSCEAR) report, New York (2008) 1.

14. A. Malanca, V. Pessina, G. Dallara et al., Appl. Radiat. Isotopes 46 (1995) 1387.

15. F. Tuo, X. Peng, Q. Zhou et al., Radiat. Prot. Dosim. 188 (2020) 316.

16. G. Yang, X. Lu, C. Zhao et al., Radiat. Prot. Dosim. 155 (2013) 512.

17. T. Sofilić, D. Barišić, U. Sofilić et al., Pol. J. Chem. Technol. 13 (2011) 23.

18. R. Trevisi, S. Risica, M. D'Alessandro et al., J. Environ. Radioact. 105 (2012) 11.

19. S. Righi and L. Bruzzi, J. Environ. Radioact. 88 (2006) 158.

20. A. Eštoková and L. Palaščáková, Int. J. Environ. Res. Public Health 10 (2013) 7165.

21. S. Turhan, U. N. Baykan and K. Sen, J. Radiol. Prot. 28 (2008) 83.

22. Anonymous, Council Directive 2013/59/Euratom laying down basic safety standards for protection against the dangers arising from exposure to ionising radiation, Official Journal of the European Union, Brussels (2015) 1 .

23. Anonymous, Exposures from natural radiation sources, United Nations Scientific Committee on the Effects of Atomic Radiation (UNSCEAR) report, New York (2000) 1.

24. A. Nwachukwu, F. Ikeagwuani and A. O. Adeboje, Atom Indonesia 47 (2021) 25. 